\title{
3 Wheel Forklift for Industrial Purposes
}

\author{
Saurabh S Shah ${ }^{1}$, Mohd Husain A Sunasara ${ }^{2}$, \\ Pramit S Jain ${ }^{3}$, Zohaib Shirgaonkar ${ }^{4}$ \\ Department of Mechanical Engineering \\ Rizvi College of Engineering \\ Bandra (W) , Mum-50, Maharashtra, India
}

\author{
Prof. Jugal Jagtap \\ (Project Guide) \\ Department of Mechanical Engineering \\ Rizvi College of Engineering \\ Bandra (W) , Mum-50, Maharashtra, India
}

\begin{abstract}
In general the forklift can be defined as the machine capable of lifting heavy weights that is difficult for an ordinary human being to lift . It is similar to vehicle but a addition of two forks to lift the weight makes the difference. The operator using these forks can lift any heavy weight material on a click of button without any effort . The forklift operator just pushes the fork below the weights and upto certain distance the weights are lifted above in air so that they can be moved accordingly as per the requirement .
\end{abstract}

Keywords : Forklift, machine, lift, weights, forks .

\section{CHAPTER 1 : INTRODUCTION}

A Forklift truck is one of the most used machines employed for several types of tasks. They range from warehouse use to large scale industry with multiple locations. They make lifting of heavy objects fast and a whole lot easier than manual lifting. There is a wide range of forklifts to select from going well with your particular requirements and necessities. Rough Terrain forklift trucks are used primarily in new construction work locations and areas where you may be on dirt or loose gravel.

Forklift trucks are either powered by propane, electricity, gasoline or diesel. Electric forklift trucks rely on the batteries to operate. Propane or gasoline forklifts are faster or stronger than electric forklifts, but they're more difficult in maintenance, \& fuel can be costly. The electric forklift trucks are great for the warehouse use as they don't give-off noxious fumes like the gas-powered machines do.

Forklifts are often used in the warehouses; however, some of them are meant to be used outdoors. Vast majority of roughterrain forklift trucks operate on propane or gasoline, but some of them are powered by natural gas or diesel. Rough terrain forklifts have the greatest lifting capacity of the entire forklifts \& heavy duty tires, making it likely to drive on uneven surfaces outdoors. Forklifts have revolutionized the warehouse work. Well-maintained \& safely operated forklift trucks make lifting \& transporting cargo infinitely easier.

The most popular forklift types on the market today are:

$\begin{array}{ll}\text { - } & \text { Warehouse forklift } \\ \text { - } & \text { Side Loader } \\ \text { - } & \text { Counterbalance Forklift } \\ \text { - } & \text { Telehandler } \\ \text { - } & \text { Industrial Forklift } \\ \text { - } & \text { Pough Terrain Forklift } \\ \text { - } & \text { Wallet Jack } \\ \text { - } & \text { Order Picker } \\ \text { - } & \text { Reach Fork Truck }\end{array}$

\section{A) SURVEY :}

The first contribution toward scientific material handling instrumentality seems to possess been the 2-wheel go-cart . During this we tend to square measure move the fabric however not carry it. In 1906, a political candidate of thePennsylvania Railroad at Altoona, supplementary accumulator power to a baggage wagon, it absolutely was the primary power truck. The primary transportable elevator on record within the Patent and Trademark Office Database was engineered of wood in 1867, with upright, cantilever platform, and a hoist. One of the first efforts to mix horizontal and vertical motion was in 1887 , once a crude truck capable of lifting its platform some inches was build. This was most likely the primary application of the unit load principle with skids. Thenin 1909, once the primary all steel carry truck appeared. In advantage of combined vertical and horizontal handling ability. It took a kind of tiny crane mounted on a platform truck. The introduction of hydraulic power and therefore the development of the primary electrical power self-propelled vehicle, beside the utilization of standardized pallets within the late Nineteen Thirties. In 1954, a British company named state capital Bagnall, currently a part of KION cluster, developed what was claimed to be the primary slim aisle electrical reach truck . Throughout Fifties to Nineteen Sixties, operator safety became a priority because of the increasing lifting heights and capacities. In our project, we tend to square measure exploitation the battery power for the horizontal movement the vehicle and therefore the human power to carry the fabric 
from the bottom . It's same because the $1^{\text {st }}$ self-propelled vehicle beside the battery power that was use in 1913 truck the easy mechanical mechanism for the lifting the fabric.

\section{B) SCOPE :}

Project work "3 WHEEL DRIVE FORKLIFT FOR INDUSTRIAL WAREHOUSE” is aimed to

Elevate the load with the assistance of chain drive. The most blessings of exploitation this can be to simply handle significant load by solely switching on the motor. It will increase the productivity. The system is meant \& developed with success, for the demonstration purpose paradigm model (mini model) would be built in future.

After collection the go back numerous journal we tend still as analysis paper there's great deal of fuel is wasted by elevating a load or significant material thus we came to conclusion that manual motor lift is that the solely thanks to stop such industrial issue like ability operator solely will operate don't seem to be needed, significant load handling and therefore the main advantage of this self-propelled vehicle is most effective, low cost \& increase productivity. Most of all the fossil fuel saving could be a major concern by exploitation hydraulic jack self-propelled vehicle. We will use human brain similarly as hands \& legs \& operate a self-propelled vehicle and thereby nullifying the possibilities of accident.

Our project options a simple electrical heart and a simple mechanical body. As this could be the sole one, we have straightforward quick the speed of the vehicle for manual operational. It's typically become any elegant application. Considering the project time and everybody the specified steps, we tend to tend to terminate this project is that the proper one. Since merely a simple modification in its mechanical arm and movement suggests that, we'll convert into any golem which can perform a special style of work. We'll use our human brain additional as body and legs to chop back external offer and wire. As this could be the sole one. It's typically become any elegant application. We tend to tend to return to conclusion that operated by hand the vehicle is cut back the worth of skilled worker \& any worker can have used our vehicle additional because of it's safe, cheap and straightforward to use and increase the productive.

\section{C) MARKET ANALYSIS :}

The market survey lets the firm to understand and realize the real demand and potential for the product under consideration. First and foremost, it is necessary to establish that the proposed product will fulfill a demand in the market or not, what is supposed to do, and the service it can offer to the consumers.

So, we take the survey for our prototype in 'SAFAR AGENCY', Vasai Virar, Virar East . There requirement of miniature forklift that can lift the component up to $500 \mathrm{Kg}$ economically.
After we surveyed in our institute we can found that the educational engineering apparatus up to $50 \mathrm{Kg}$ is not easy to move from one place to another place. So the miniature forklift is required to design that can utilized for lifting load up to $50 \mathrm{Kg}$.

The material required for the frame was selected according to the low in cost, availability and strength. A square tube is the best as it will provide adequate strength and less in weight .Selecting any section of I or C type would give strength more but it will be an over design structure according to the capacity.

The warning lights and sound is compiled in a small circuit system that includes small system and the PCB would be bought at VISHA AND VEGA KIT , in Grant Road , Mumbai.

The wheels of electric vehicle would be available as Tyre Stores 4 SEASON, in MAHALAKSHMI. They have an inventory of recycling old tyres and would be available in cheaper rates and according to the requirement wheel height .

Chain drive system is available at the sakinaka PATEL Workshop, sakinaka. The best economical manufacturer in the budget .

Steel plate for the frame above support system would be available easily at best workshop at SANATACRUZ.

\section{D) MANUFACTURING SCENARIO :}

The manufacturing process of the project would be done at the workshop .The availabilty of the workshop is at one of our group members in MAZGAON . All the equipments required for manufacturing like cutter, grinder, welding equipments, and other safety equipments are available.

\section{CHAPTER 3 : PROPOSED SYSTEM}

\section{A\} METHODOLOGY}

The industrial forklift are huge in size. Though they have several advantages, there is a need for better forklift model for small scale puposes. Concern is to be given to improve the following aspects in the existing forklift,

The frame should have high load taking capability.

The frame should provide a better stability to the whole system.

Reducing the size for small scale industrial purposes having space constraint.

The manufacturing cost should be minimized by minimizing components used and making it efficient in working . 


\section{B) DESIGN DETAILS}

\section{Forklift Description :}

A forklift is a machine which helps in moving a heavy load from place to place as per the requirement. It provides an industry to work efficiently and its much time saving in optimization of a working cycle.

Functions of forklift :

Its function is to transport the goods over short distance as when the requirement occurs. It must control the load and goods in the correct alignment to meet the conflicting requirements of stable running on straight track and good curving performance with low track wear. At same time, it must also provide acceptable ride levels in the vehicle to which it is fitted, under a wide range of track conditions.

- Support the goods being lifted.

- Run stably on both straight and curved track.

- Ensure good ride comfort by absorbing vibration generated by track irregularities and minimizing impact .

- Minimize energy or manpower required to lift a weight .

- Forklift have forks to lift the weight easily and manually, brake arrangement, axle box guide and many other parts which are welded to the frame.

- The main purpose of the forklift is to transfer the load from a manufacturing area to the inventory area of the industry efficiently and it would be time saving approach.

- $\quad$ These wheels support the load tranfering the force of the load to the rear part hence tranfering the overall $C G$ point of the forklift .

\section{Working Principle :}

The wheel shaft is connected with arrangement of a motor. This motor is used to run the vehicle. Battery is connected to the motor. The motor is connected to the chain drive to increase the torque and is directly coupled to the wheel by means of a bearing block which runs the vehicle. Motor is controlled by the control unit This vehicle causes no pollution. In front of the Segway the forklift arrangement is mounted. The sprocket is used lift the fork and used to move up and down. The most important consideration of designing a fork lifts is the safety, while the forklifts is during the loading and moving stability system consists of 3 point of contacts , 2 front wheel drives and supporting the real wheel contact axle arranged on safely mounted.

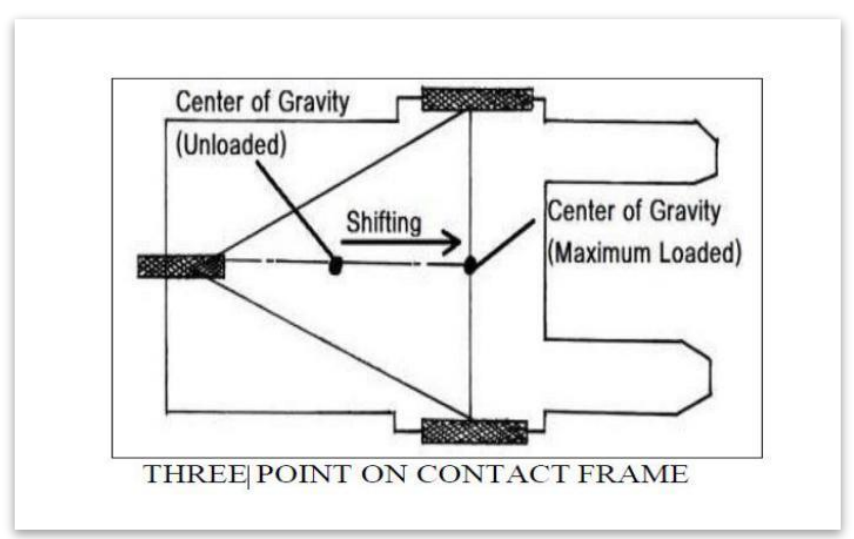

FIGURE 1 : THREE POINT CONTACT

\section{Forklift Components :}

Forklifts are very important in safe and industrial operations and in performing some functions. The forklift are the undercarriage which supports the goods. In mechanical terms, a forklift consists of is a chassis or framework with wheels, thus serving as a modular subassembly of wheels and axles. The forklift has following components :

\section{a) Forklift Frame}

The forklift frameis known as the main supporting system. The bogie frame is either casted or fabricated. The forklift frames are manufactured based on its working conditions. It is the main component which takes the stresses. The forklift frame is designed in such a way that it can take the load of the goods, operator as well as the components attached to it with proper body weights balance.

\section{b) Forks}

The forks are the main element which are made to take up the load of the goods being lifted. These are the most stressed elements as it involves variable loading condition during lifting and loading. These components are generally low in cost and made up of cast iron. Hence such elements need to be analysed properly and a proper maintenance should be done by removing the rust scales, polishing or others.

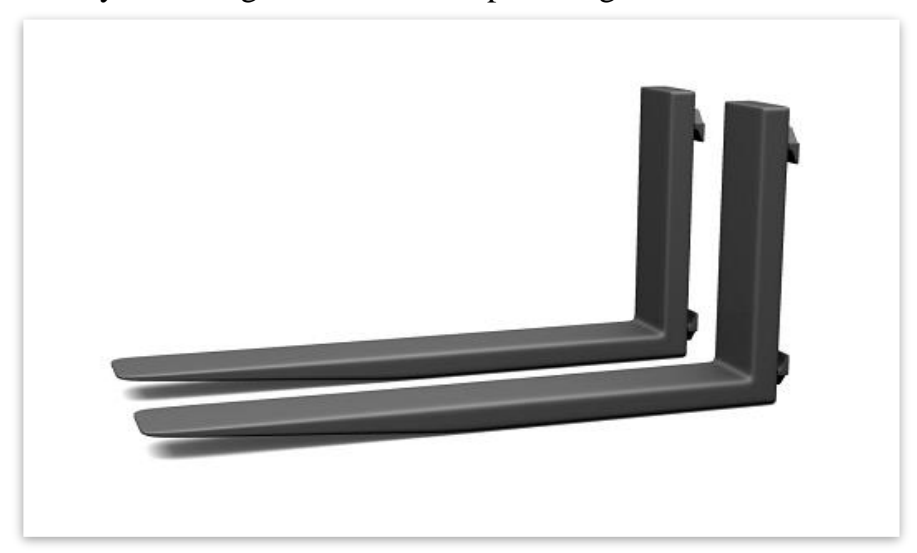

FIGURE 2 : FORK 


\section{c) Brake}

A pair of Drum brake is provided on driving wheel. The brake actuating mechanism would be underlying the frame next to the connected with the link mechanism such that the it would lock the axle when required .

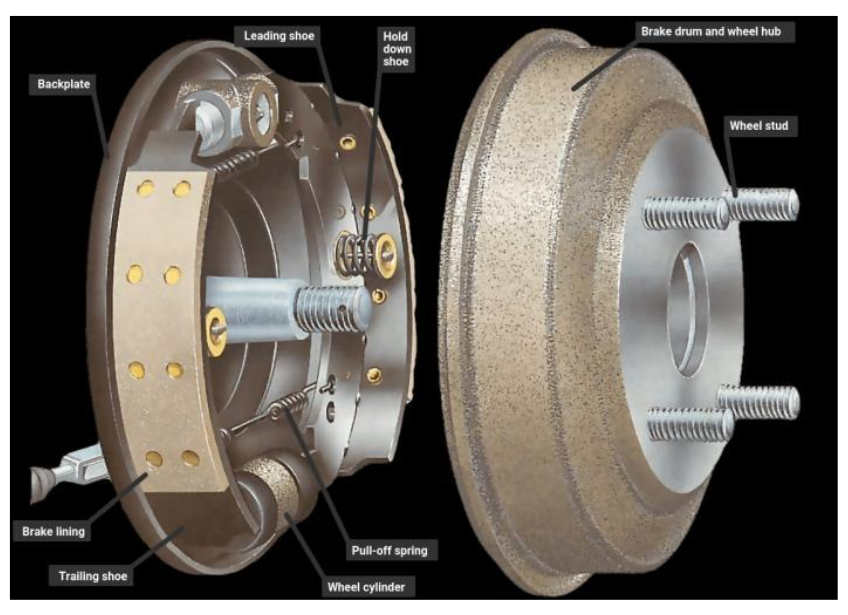

FIGURE 3 : DRUM BRAKE

\section{d) Motor}

The driving axle would be connected to the motor with the help of chain drive. It drives the axle through chain drive .The sprocket is mounted on the axle and will be connected to the driving axle connected with two front wheels .

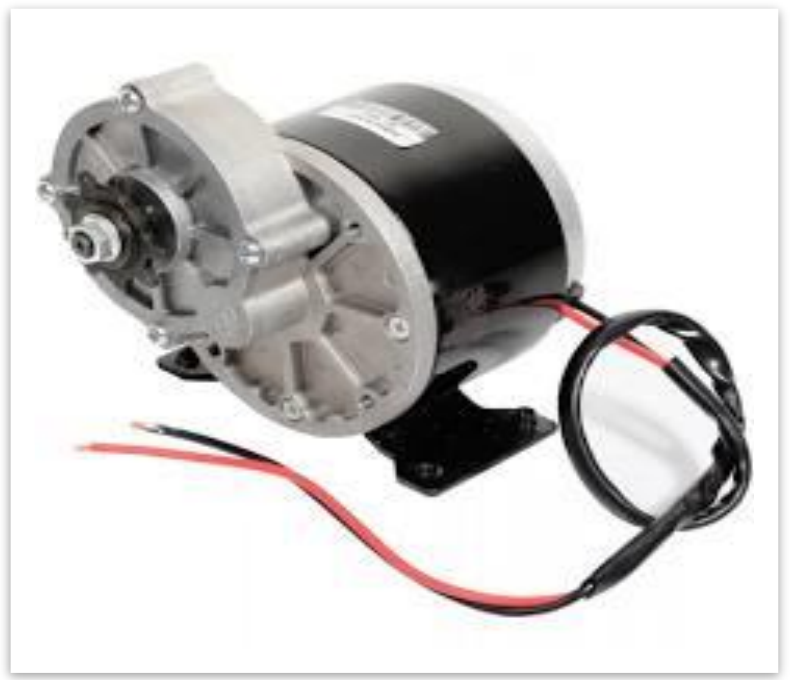

FIGURE 4 : HIGH GEARED MOTOR

\section{e) Chain drive}

The chain drive will be used in the system to increase the gear ratio or increase torque transmitting capability to the driving wheels as would require hi starting torque due to its own weight and the external load (goods). The larger sprocket would be mounted on the driving axle shaft and it would be connected via key and sprocket and the smaller gear would be mounted on the motor.The material for chain is medium carbon steel blank form cold rolled sheet hardened to 50 HRC. The pin, bushes and rollers are made up of case carburizing alloy steel and hardened to $50 \mathrm{HRC}$ as well.

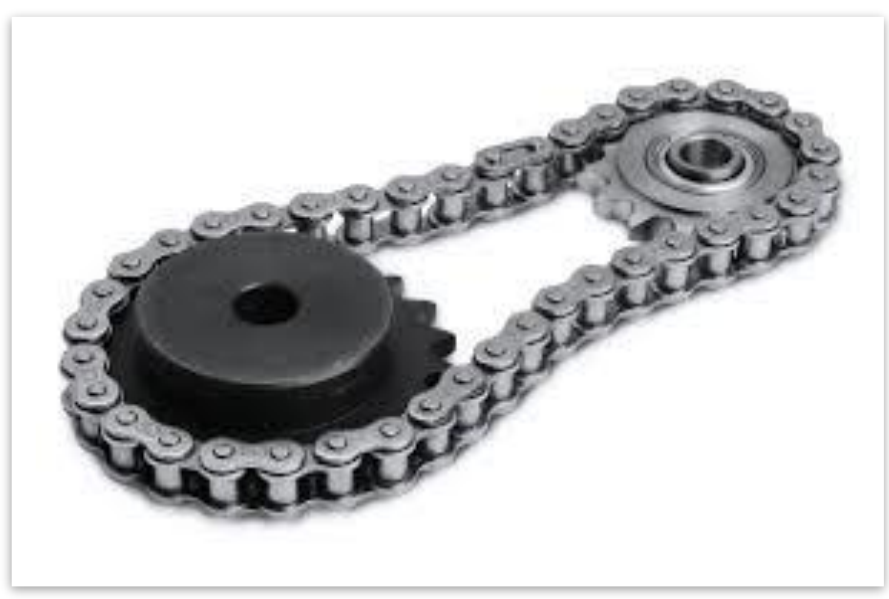

FIGURE 5 : CHAIN AND SPROCKET DRIVE

\section{f) Shaft}

A shaft is for mounting the wheels, gears . It is designed based on the ASME code approach as it is very convenient and conservative approach to get an accurate dimension of the shaft. The most popularly used shaft material would be medium carben steel due to its properties of, low in cost, readily availaible, high toughness, good strength and high load taking capability.

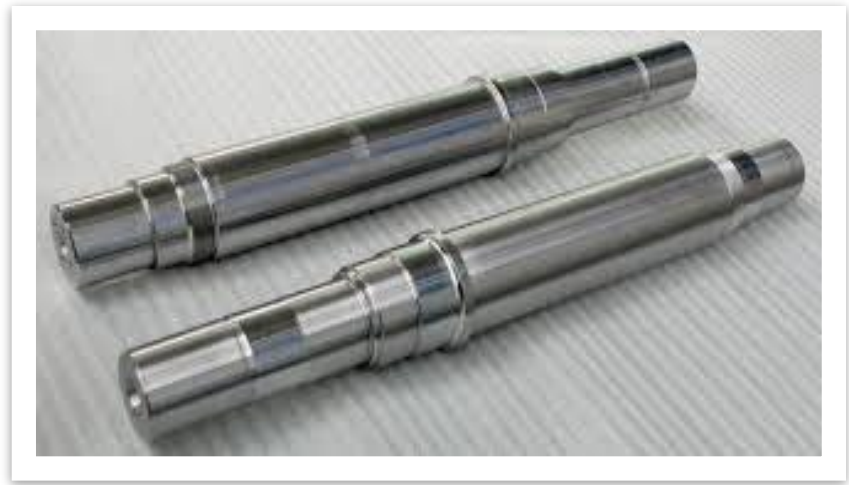

\section{FIGURE 6 : SHAFT}

g) Square tubes

The square tubes form support structure to the body of the forklift. This structure is always under a repeated loading condition as the requirement vary according the load or application. These are made of Mild Steel material with appropriate strength and having the property of good weldability. 


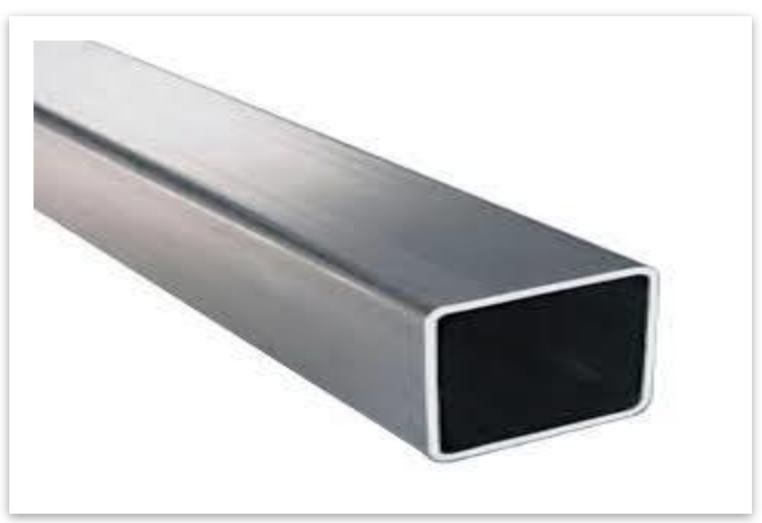

FIGURE 7 : SQUARE TUBE

\section{h) Actuators}

The actuators like accelerator would be use to control the speed, brake mechanism, switches to turn on the motor .

\section{i) Wheels}

The wheels of two different type would be used. The front wheels would of same type and would vary from rear. The front wheels have their centre at good height so that a good amount of ground clearance would be achieved and it also help the goods to at proper and safe height from the ground so that it doesn't cause any harm while moving the object. This also propose an important cause of getting the shift of centre of gravity of the forklift at rear which would avoid its toppling . The front wheel used would be of Activa bike.

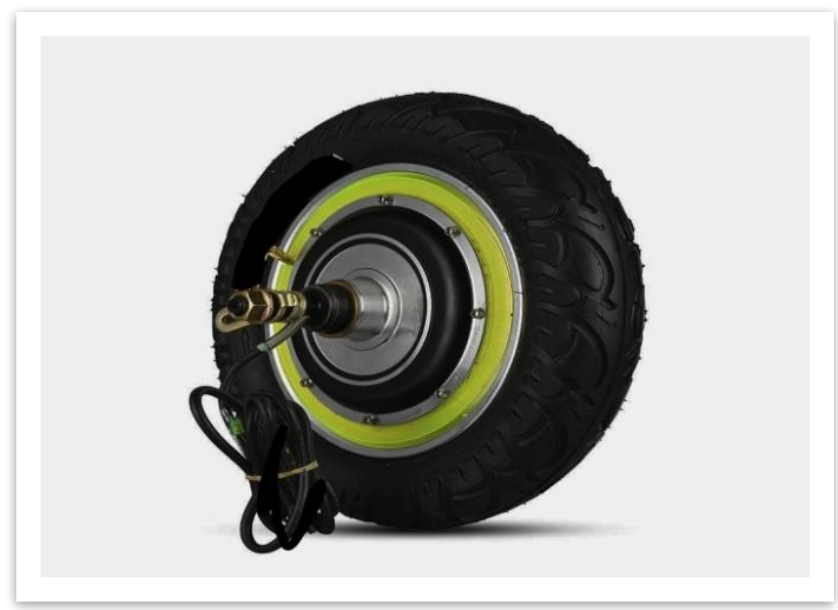

FIGURE 8 : FRONT WHEEL

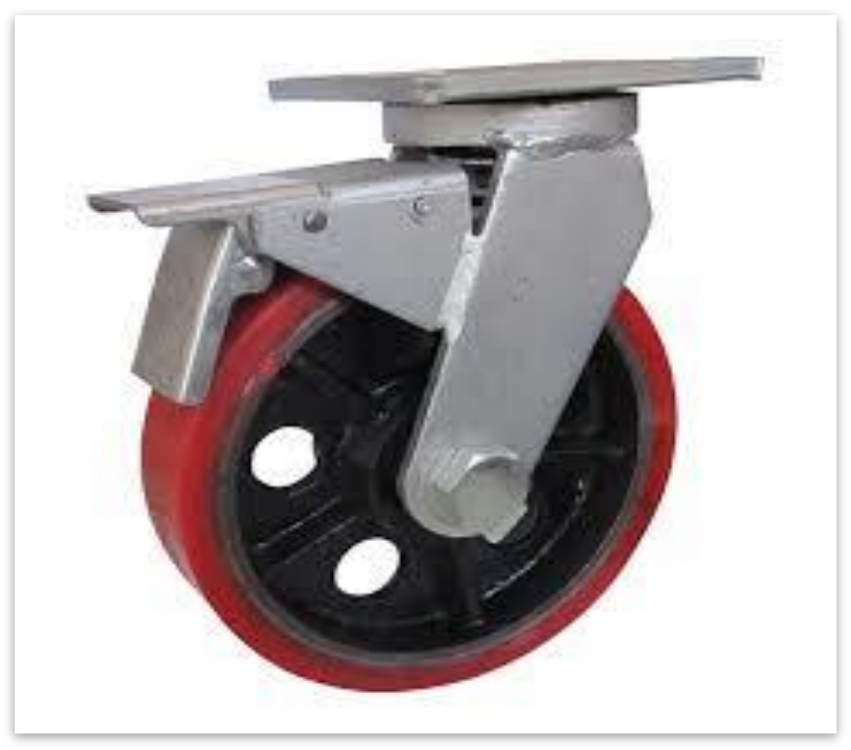

FIGURE 9 : REAR WHEEL

\section{j) Steel plate}

These plates would be mounted as a platform above the frame and will carry the load of the operator. These plate are of steel having grids to provide a good frictional grip. These can be popularly observed in the BEST buses.

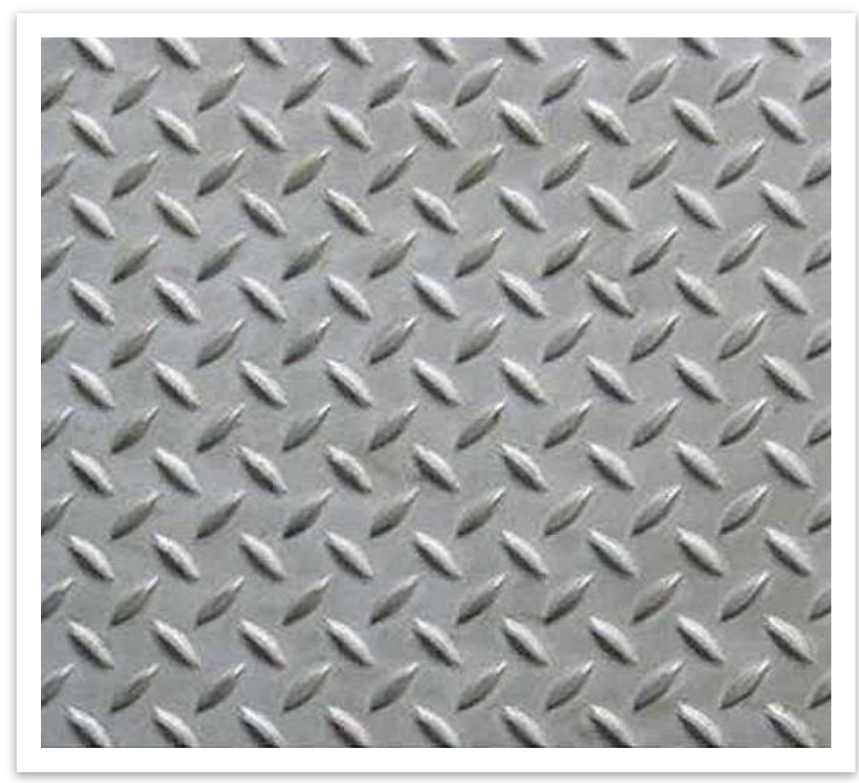

FIGURE 10 : STEEL BASE PLATE 


\section{k) Warning lights}

These are provided to show that the forklift is engaged

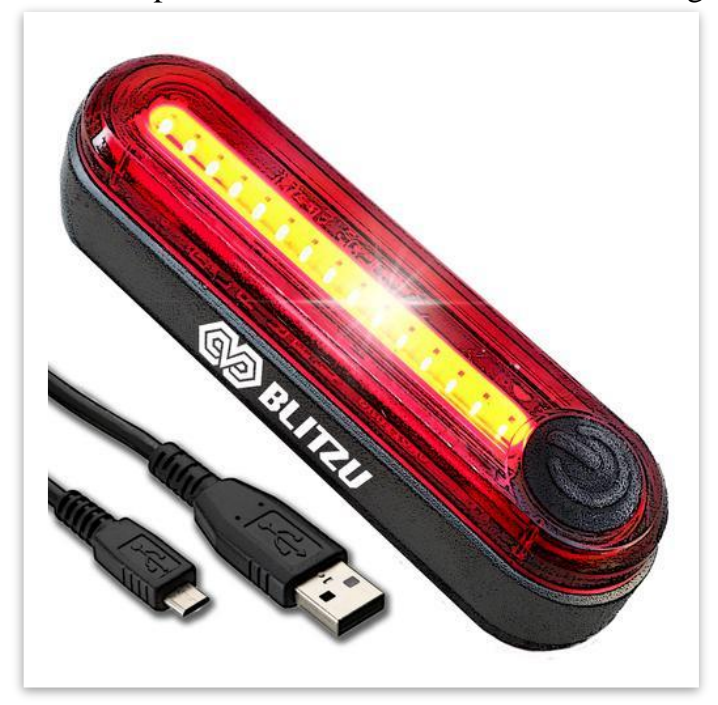

FIGURE 11 : WARNING LIGHT

1) Warning indicator circuit

These are provided to indicate the forklift is in performing its operation .

CHAPTER 4 : DESIGN OF FORKLIFT

\section{A\} DESIGN OF FORKS}

\section{MOMENT OF INERTIA OF FORK :}

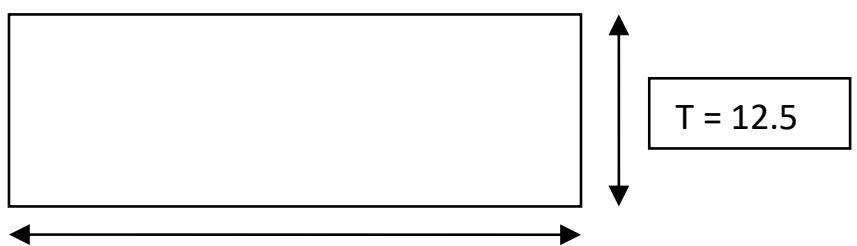

$$
B=40 \mathrm{~mm}
$$

FIGURE 12 : CROSSECTION OF FORK

$$
\text { - } \quad \mathbf{L}=\mathbf{5 0 0} \mathbf{~ m m}
$$

- $\quad$ MOMENT OF INERTIA OF FORK :

$$
\begin{aligned}
\mathrm{I}_{1}=\mathrm{I}_{2} & =\frac{B D^{3}}{12} \\
& =\frac{12.5 \times 40^{3}}{12} \\
& =66666.66 \mathrm{~mm}^{4}
\end{aligned}
$$

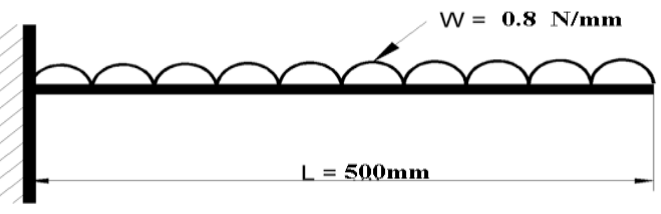

FIGURE 13 : LOADING ON FORK

\section{NOW CONSIDERING UNIFORMLY DISTRIBUTED}

LOAD ,

1. Moment of inertia of two fork

$$
\begin{aligned}
\mathrm{I} & =\mathrm{I}_{1}+\mathrm{I}_{2} \\
& =133333.33 \mathrm{~mm}^{4}
\end{aligned}
$$

2. Find $\mathrm{W} / \mathrm{mm}$

$$
\begin{aligned}
\mathrm{W} / \mathrm{mm}= & \mathrm{W} / \mathrm{L} \\
& =\frac{400}{500} \\
& =0.8 \mathrm{~N} / \mathrm{mm}
\end{aligned}
$$

3. Bending moment $(\mathrm{M})$

$$
\begin{aligned}
& M=\frac{\left(-W \times L^{2}\right)}{2} \\
& =\frac{-0.8 \times 500^{2}}{2} \\
& =-100000 \mathrm{Nmm}
\end{aligned}
$$

4. Deflection $\left(\mathrm{Y}_{\max }\right)$

$$
\begin{aligned}
\mathrm{Y}_{\max } & =\frac{W \times L^{4}}{8 E I} \\
& =\frac{0.8 \times 500^{4}}{8 \times 150 \times 10^{3} \times 133333.33} \\
\mathrm{Y}_{\max } & =3.125 \mathrm{~mm}
\end{aligned}
$$

B) ANALYSIS :

FINITE ELEMENT ANALYSIS OF FORK :

- $\quad$ Mesh Size Selection For Analysis

Mesh sizes calculated by plotting a graph between deformation and mesh size from $1 \mathrm{~mm}$ to $15 \mathrm{~mm}$ for various iterations. Hence a mesh size of $7 \mathrm{~mm}$ is selected as the deformation becomes constant. It means that there will be negligible changes in the accuracy of the results on the further reduction in the mesh size. 


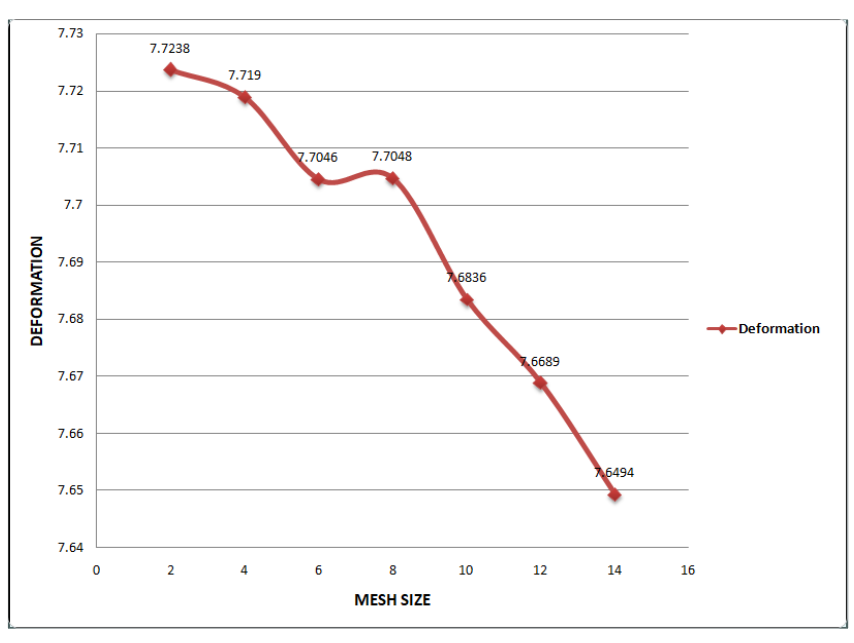

FIGURE 14 : MESH SIZE GRAPH
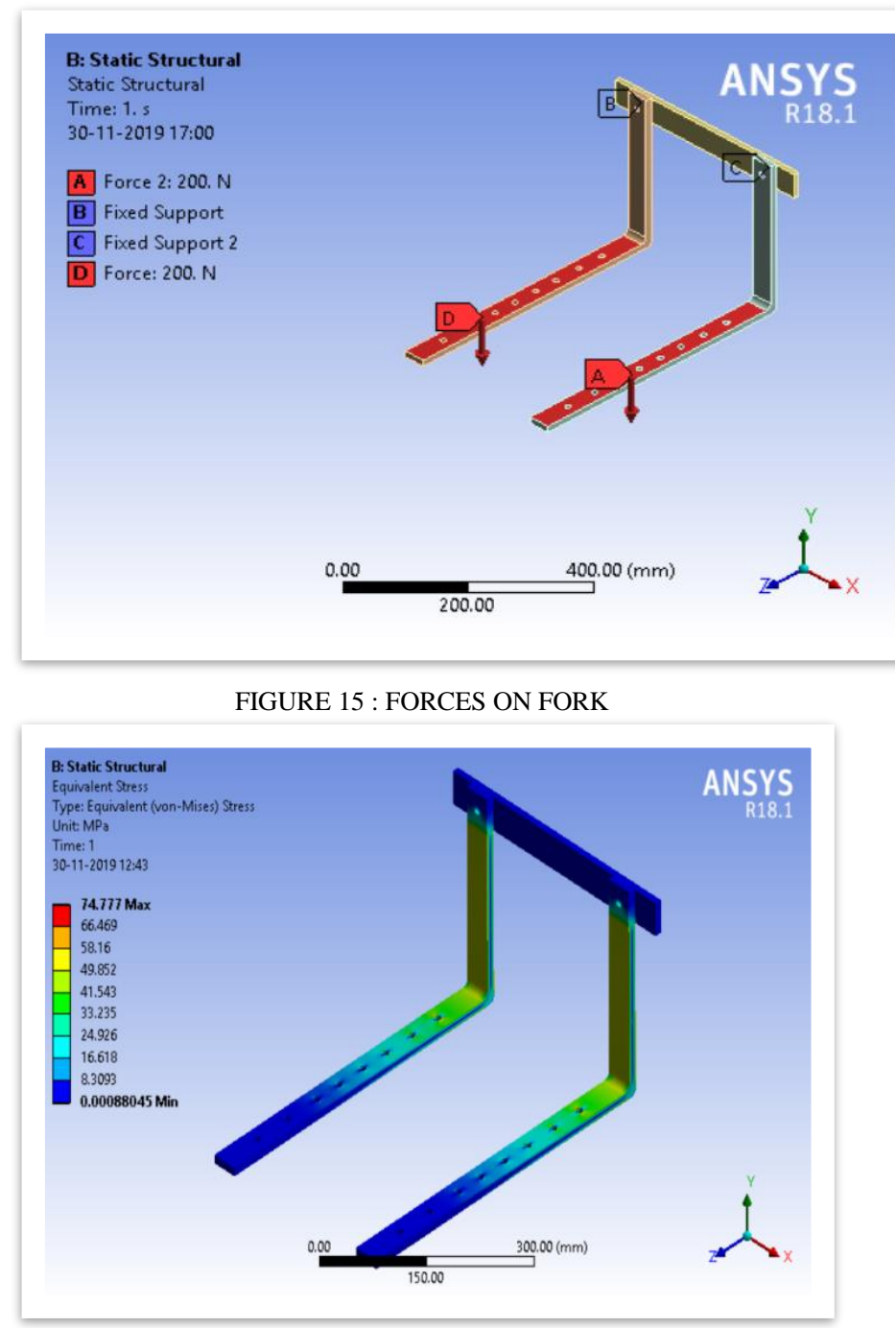

FIGURE 16 : STRESS ON FORK

\section{C) DESIGN OF ERGONOMICS :}

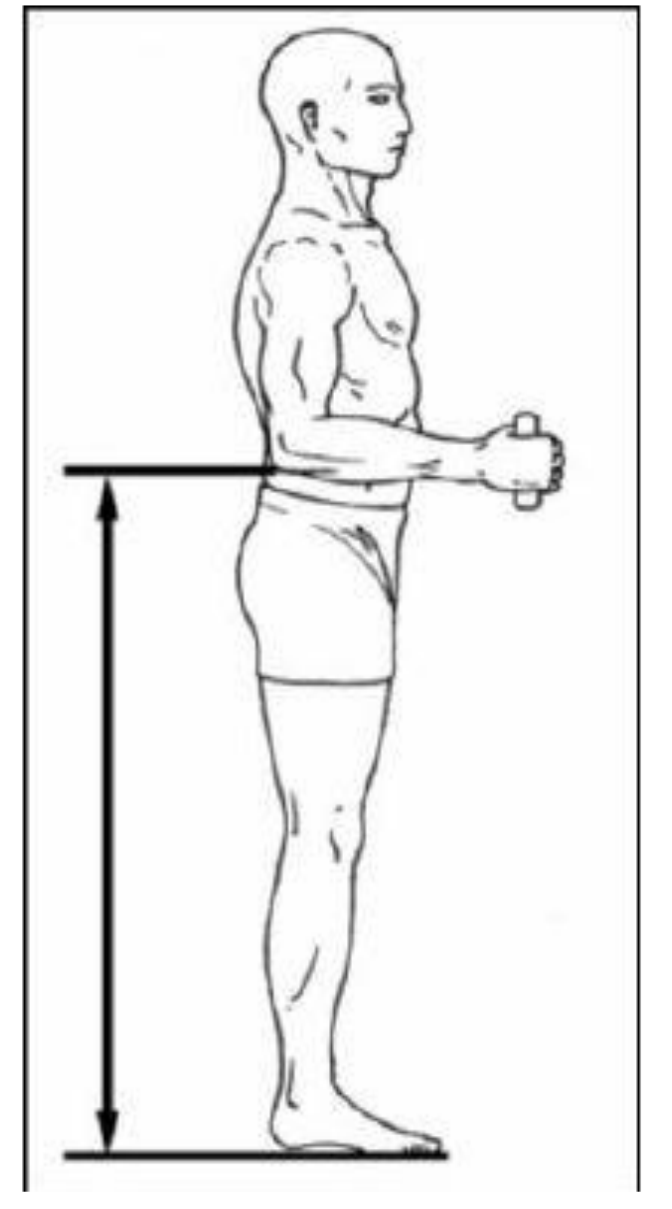

FIGURE 17 : AVERAGE WAIST HEIGHT

1. Determine Height of Handle from Base-

Female -

- $\quad 997.9 \mathrm{~mm}$ Mean

- $\quad 1185.0 \mathrm{~mm}$ Maximum

- $\quad$ 856.0mm Minimum

Male -

- $\quad 1072.5 \mathrm{~mm}$ Mean

- $\quad 1261.0 \mathrm{~mm}$ Maximum

- $\quad 888.0 \mathrm{~mm}$ Minimum

a) Taking average of male $\&$ female mean-

$(997.9+1072.5) / 2=1035.2 \mathrm{~mm}$

As we know in workplaces workers always wears shoes or any kind of footwear so the thickness of footwear is also to be taken into account. So considering normal shoe sole is approximately $25.4 \mathrm{~mm}$. 
b) Adding this extra height in average-

$1035.2+25.4=1060.6 \mathrm{~mm}$

So the height of handle from base is $1060 \mathrm{~mm}$.

2. Determine Width of Handle -

Female-

- $\quad 468.5 \mathrm{~mm}$ Mean

- $\quad 609.0 \mathrm{~mm}$ Maximum

- $\quad 373.0 \mathrm{~mm}$ Minimum

Male-

- $\quad 546.1 \mathrm{~mm}$ Mean

- $\quad 725.2 \mathrm{~mm}$ Maximum

- $\quad 399.0 \mathrm{~mm}$ Minimum

a) Taking average of male female mean

$(468.5+546.1) / 2=507.3 \mathrm{~mm}$

We have to provide extra length as allowance

So providing allowance of $45 \mathrm{~mm}$

b) Adding extra length of allowance-

$507.3+45=560 \mathrm{~mm}$

So total length of handle bar is $560 \mathrm{~mm}$

D) FRAME :

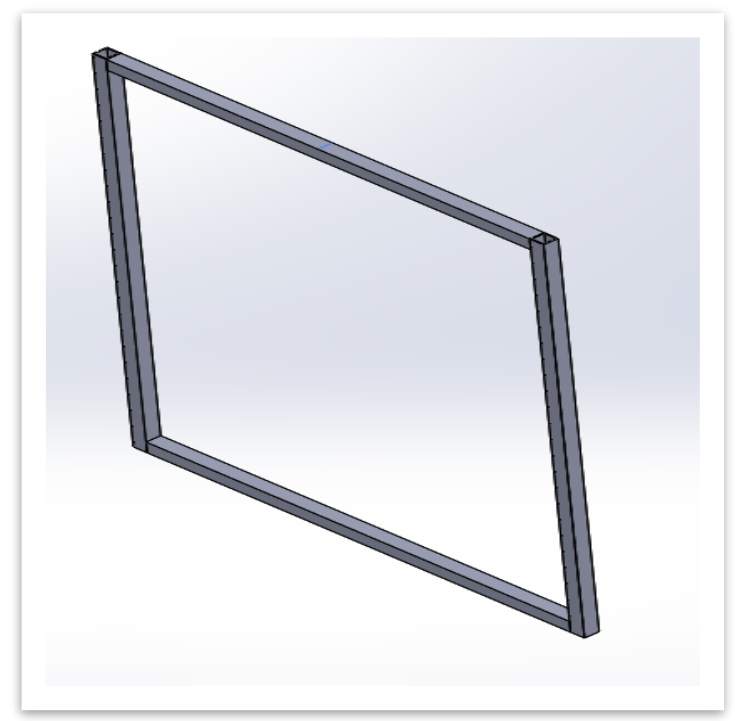

FIGURE 18 : BASE FRAME

Frame is being made using square tube made up of mild steel having good properties and it can be way better to make using these material as it is less in cost, readily available and sufficient material property for the purpose it is used in .

\section{A] Frame Analysis :}

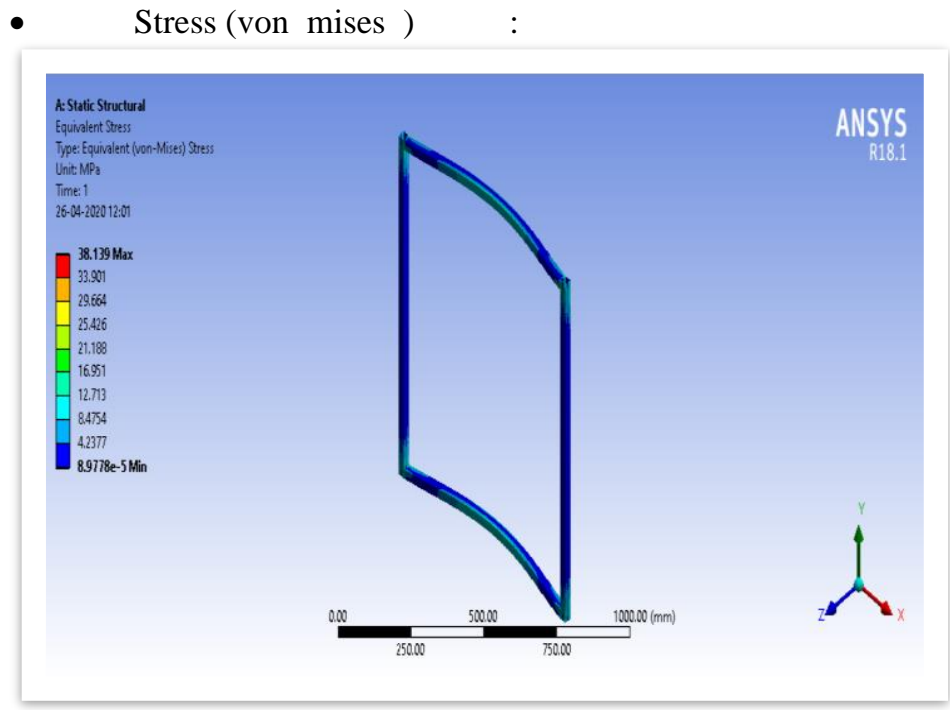

FIGURE 19 : STRESS ON BASE FRAME

- $\quad$ Factor of safety :

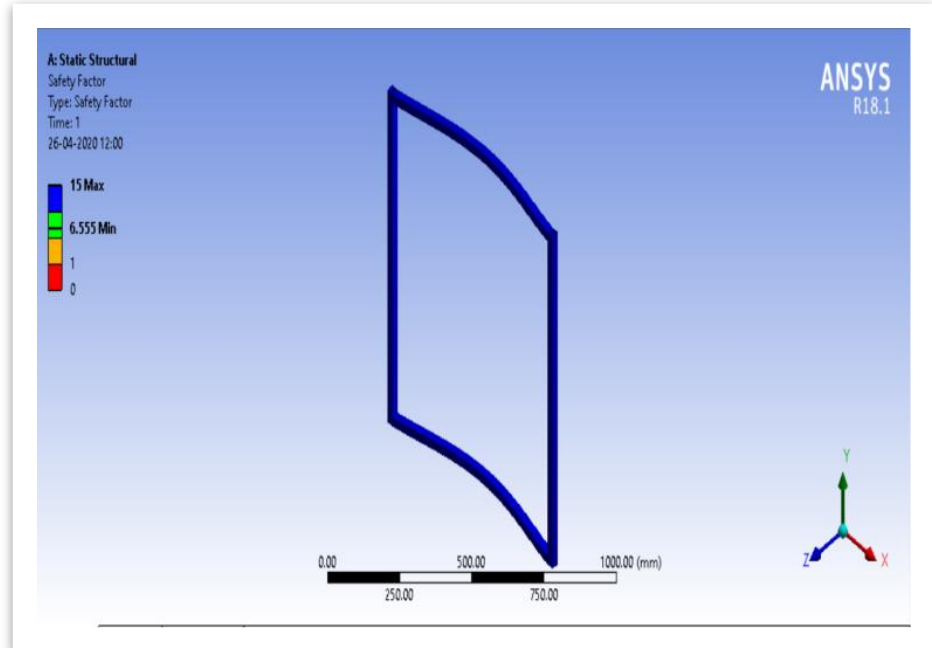

FIGURE 20 : FOS OF FRAME

- Deformation :

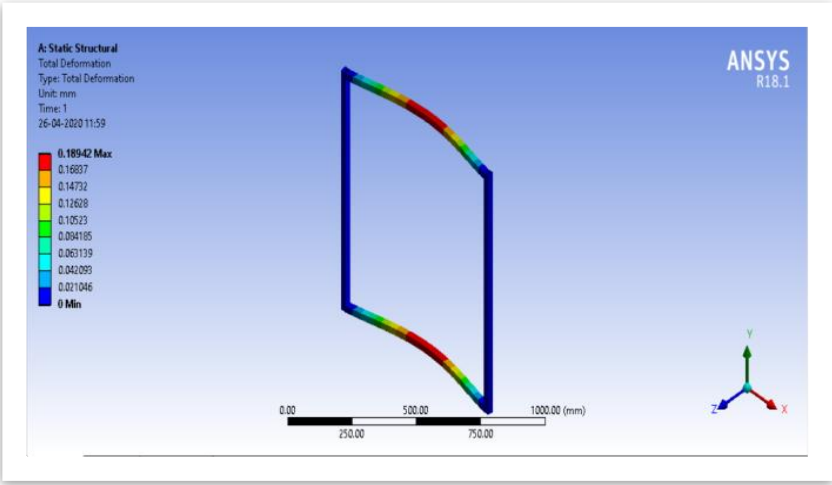

FIGURE 21 : TOTAL DEFORMATION OF FRAME 


\section{E\} HANDLE :}

The handle has been added and many holes are provided such that the driver can adjust the handle accordingly to his comfort . The selected handle is of hollow type as it would be in low in cost, less in weight and the throttle wires can be incorporated through it .

\section{Inner handle :}

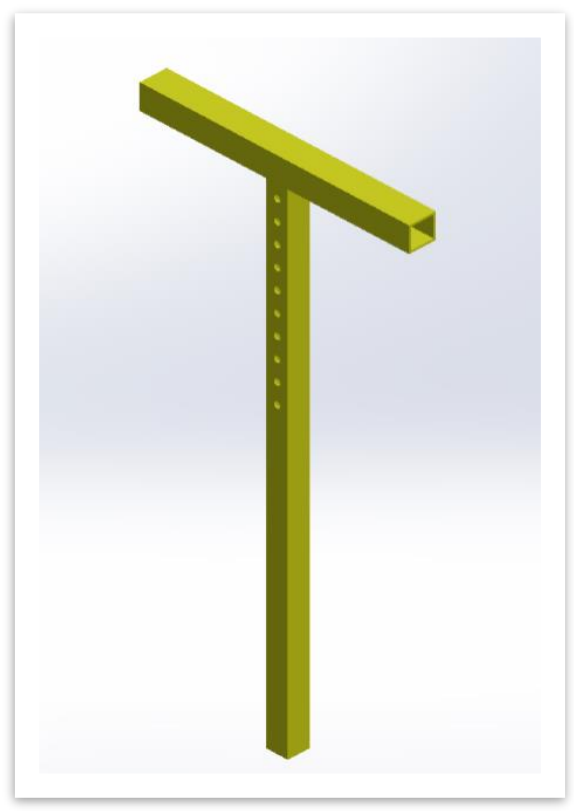

FIGURE 22 : INNER HANDLE

\section{Outer handle :}

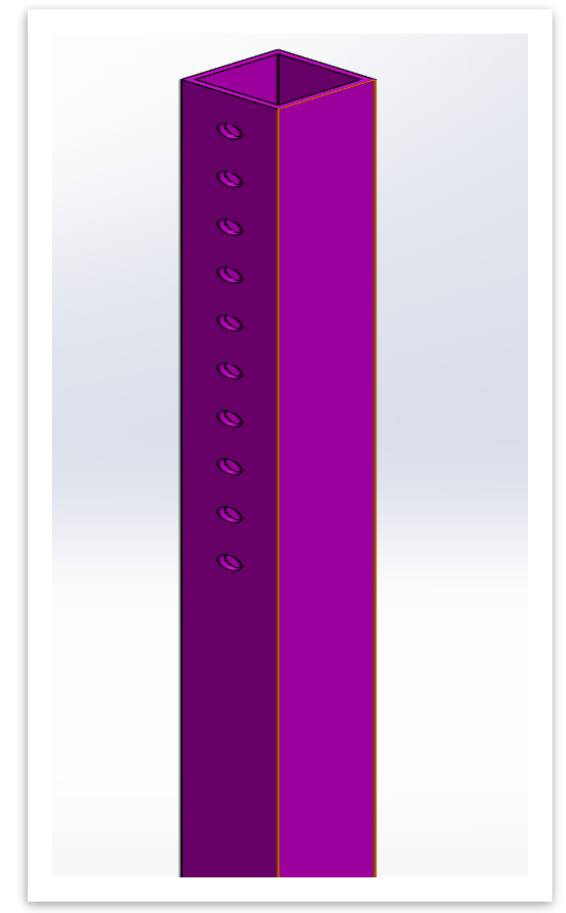

FIGURE 23 : OUTER HANDLE

\section{Assembly :}

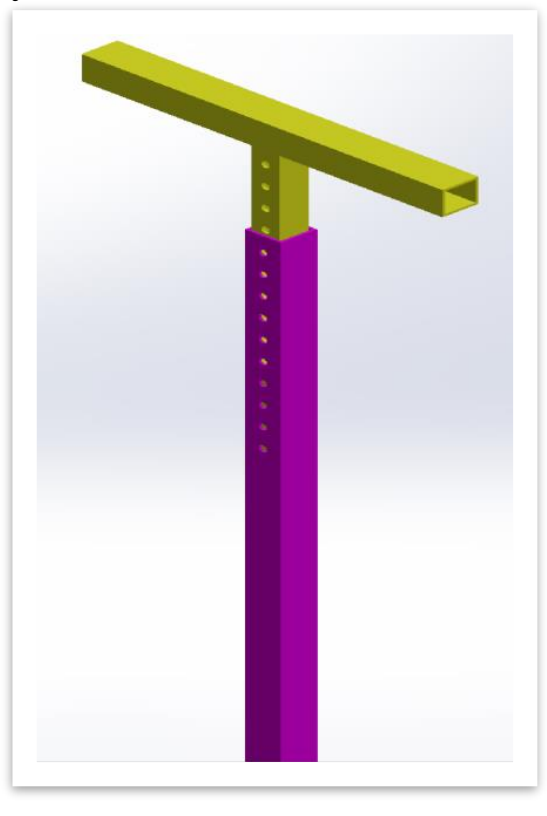

FIGURE 24 : ASSEMBLY OF HANDLE

\section{F\} MOTOR SELECTION AND LOAD CALCULATIONS :}

Selecting , PMDC (Permanent Magnet Direct Current ) reversible motor and we have following options.

$$
\begin{array}{ll}
12 \text { volt } & \text { non geared } \\
12 \text { volt } & \text { geared } \\
24 \text { volt } & \text { non geared } \\
24 \text { volt } & \text { geared }
\end{array}
$$

As we are lifting heavy load and our application is forklift . And we are not just lifting but also we have to stop weight at different height and again have to come down for this we are going with PMDC $24 \mathrm{~V}$ reversible geared motor and going with $1440 \mathrm{rpm}$ as compromise between cost and performance.

We are doing two different operations with the help of motor.

Lifting(using 1 motor)

Driving (using two motor on front tire with throttle)

\section{Lifting :}

For Lifting in which we are using motor with pulley and motor having power rating of $125 \mathrm{~W}$ Which is giving approximately $170 \mathrm{Nm}$ torque which can lift easily up to 45 $\mathrm{kg}$. Hence we are going with this PMDC reversible motor having this much of torque and output speed of $30 \mathrm{rpm}$. 


\section{Load calculations :}

Total load that has to lifted by motor $=$ weight which has to lift + f ork weight + some extra

$$
=20+7+3=30
$$

$\mathrm{kg} \leq$ loading capacity

Our motor can easily take load therefore safe for capacity,

Velocity of lifting $=\pi \times$ pulley dia $\times$ output speed

$$
\begin{aligned}
& =\pi \times 0.07 \times 30 \\
& =6.59 \mathrm{~m} / \mathrm{min}
\end{aligned}
$$

Since recommended maximum velocity of lifting is 8 to 10 $\mathrm{m} / \mathrm{min}$ such that no accident takes place because of inertia,

Velocity $=6.59 \mathrm{~m} / \mathrm{min} \leq 8 \mathrm{~m} / \mathrm{min}$, hence safe

\section{Driving :}

For driving we are using 2 motor on front tire separately of PMDC type because manufacturer are using same motor can easily take $80 \mathrm{~kg}$ load as we are using two such motor can easily take $150 \mathrm{~kg}$ with throttle system and motors are reversible and having output speed is 500 such we can use in reverse mode.

It has to carry lifting mechanism weight in addition to that body, motor and battery weights and drive it maximum up to 8 miles per hour but in risky area it should operate at 3 miles per hour without load and in loaded condition speed should not exceed 3 miles per hour as recommended for safety as we know steering and braking of forklift are not so responsive so it suggest take safety as government and industry norms.

\section{Load calculations :}

Total load $=$ total load lifted + driver weight + battery and body weight

$$
\begin{aligned}
& =30+50+20=100 \mathrm{~kg} \leq \\
& \text { loading capacity }
\end{aligned}
$$

Our motor can easily take load therefore safe capacity

Velocity of vehicle $=\pi \times$ tire dia $\times$ output speed

$$
\begin{aligned}
& =\pi \times 0.3 \times 200 \times \frac{3.6}{60} \\
& =11 \mathrm{kmph} \\
& =6.83 \leq 8 \mathrm{miles} / \mathrm{hr}
\end{aligned}
$$

Which is within the range recommended hence safe

\section{G) BATTERY CALCULATIONS :}

Battery Size in $\mathrm{AH}=\frac{W \times H}{V}$

$$
\mathrm{W}=\text { Total load }=300 \text { watt } \text { (assuming the }
$$

maximum of $50 \mathrm{~kg}$ load can be lifted and drive the motor for the wheel as well)

$\mathrm{H}=$ Backup time in hours $=6$ hours (assumption ... for $4 \mathrm{hrs}$ testing and $2 \mathrm{hrs}$ for presentation)

$$
\mathrm{V}=\text { battery voltage }=12 \text { volt }
$$

Load Assumption = 300 watt

$$
\begin{aligned}
& =\frac{\text { total load } \times \text { backup time in hours }}{\text { battery voltage }} \\
& =\frac{300 \times 6}{12}
\end{aligned}
$$

$=150 \mathrm{AH}$ (standard size available )

Since, the motor is of $24 \mathrm{~V}$, hence 2 batteries of $12 \mathrm{~V}$ each would be connected in series .

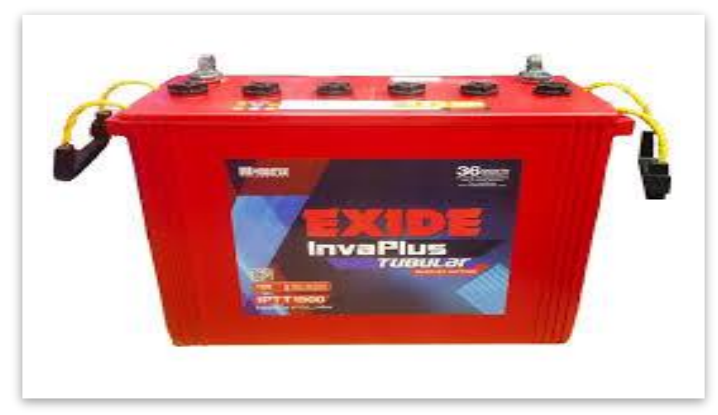

FIGURE 25 : BATTERY

\section{H\} BRAKE CALCULATIONS :}

Brakes are very important system of any vehicle or machine .It is used to control Vehicle i.e to make vehicle stop or slowing down the speed .It does this by converting mechanical energy into heat energy by means of friction

In our case our brake force boost by means of lever, spring and other parts. And we are going with drum as matter of cost and accessibility in loaded vehicle .

The normal man can generate maximum 45 Newton force with one hand because of mechanical linkage it maximises by three to four times 
- $\quad$ Force applied on lever $=45 \mathrm{~N}$

- Calculation of required brake force,

$\mathrm{F}_{\mathrm{b}}=\mu \times \mathrm{w}=0.35 \times 100=37.5 \mathrm{~N}$

- $\quad$ Required torque ,

$$
\begin{aligned}
\mathrm{T}_{\mathrm{b}} & =\mathrm{F}_{\mathrm{b}} \times \mathrm{R} \text { (drum radius) } \\
& =37.5 \times 0.065=2.43 \mathrm{Nm}
\end{aligned}
$$

- Calculation of force generated by system,

$$
\begin{aligned}
\mathrm{F}_{\mathrm{b}}= & 45 \times \text { mechanical advantage } \\
& (\ldots . .3 \text { to } 4 \text { times }) \\
& =45 \times 3=135 \mathrm{~N}
\end{aligned}
$$

- Generated brake torque,

$$
\begin{aligned}
T_{b} & =F_{b} \times \text { drum radius } \\
& =135 \times 0.065=8.8 \mathrm{Nm}
\end{aligned}
$$

- $\quad$ Stopping distance,

$$
\text { At } 20 \mathrm{kmph}
$$

Full load,

$$
S=\frac{.5 \times \text { mass of vehicle } \times \text { velocity }}{2}
$$

(By work energy principle)

$$
\begin{aligned}
& =\frac{.5 \times 100 \times 5.55^{2}}{2 \times 135} \\
& =5.7 \mathrm{~m}
\end{aligned}
$$

Without load,

$$
S=\frac{.5 \times \text { mass of vehicle } \times \text { velocity }}{2}
$$

(By work energy principle )

$$
\begin{aligned}
& =\frac{.5 \times 70 \times 5.55^{2}}{2 \times 135} \\
= & 4 \mathrm{~m}
\end{aligned}
$$

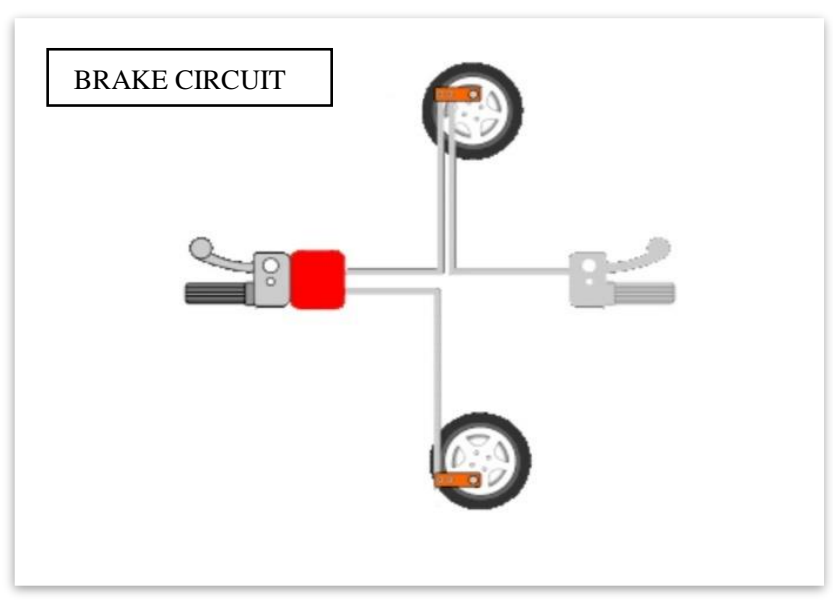

FIGURE 26 : BRAKE CIRCUIT

\section{I) EXPECTED WEIGHT :}

\begin{tabular}{|l|c|}
\multicolumn{1}{|c|}{ COMPONENTS } & WEIGHT (KG) \\
\hline $\begin{array}{l}\text { FRAME, MOTOR , FORK, } \\
\text { BATTERY }\end{array}$ & $\mathbf{3 0}$ \\
\hline DRIVER & $\mathbf{5 0}$ \\
\hline LIFTING WEIGHT & $\mathbf{3 0}$ \\
\hline WHEELS & $\mathbf{1 0}$ \\
\hline
\end{tabular}

\section{J) WHEEL LOADS :}

The below figure shows the load acting on the wheel due to the components involved in the forklift .

The brake torque would be developed on the wheel while braking and that would be equal to $8.8 \mathrm{Nm}$.

The maximum turning moment on the wheels due to the driven motor would be $170 \mathrm{Nm}$. 


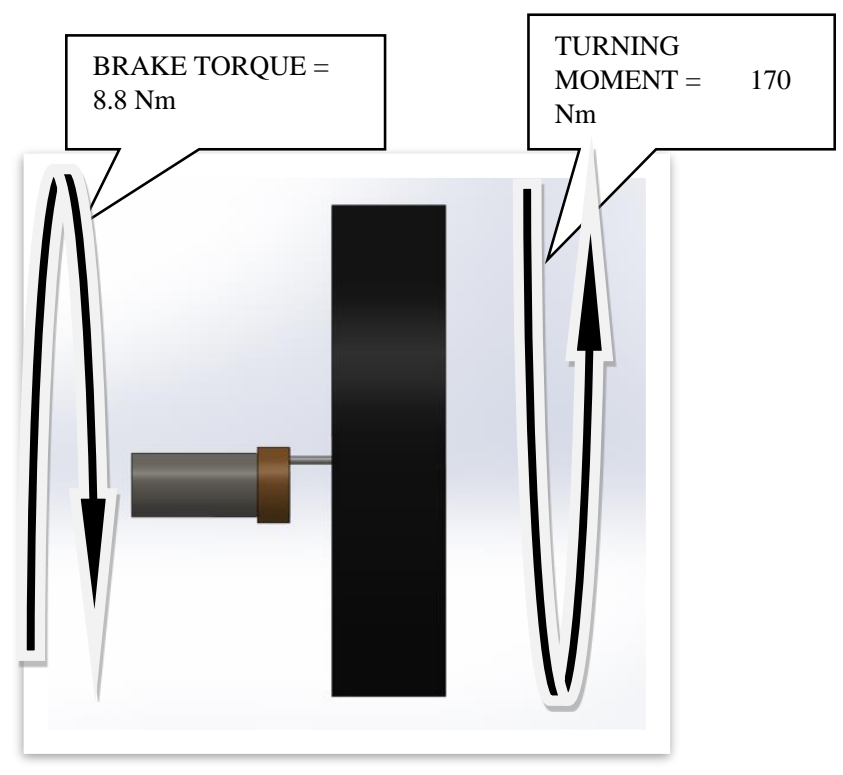

FIGURE 27 : WHEEL LOADS

\section{K\} WEIGHT DISTRIBUTION :}

The weight distribution would be $50: 50$ in front and back . The drivers weight would be accounted in the rear.

\section{L\} STEERING SYSTEM :}

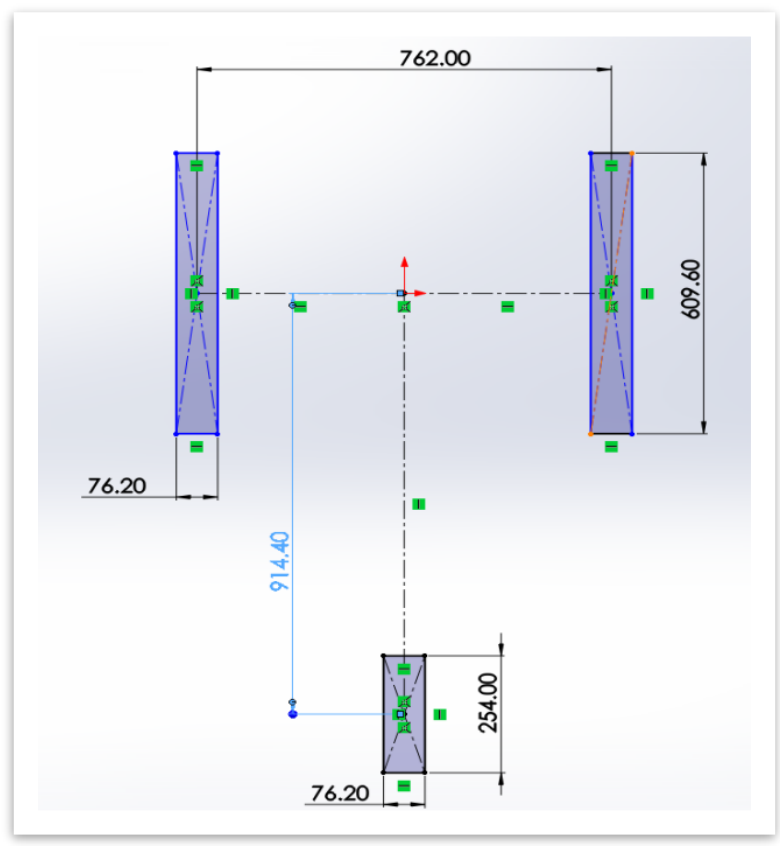

FIGURE 28 : STEERING DIAGRAM

\section{- TURNING MECHANISM :}

The turning mechanism is the best and a innovative here rather than ordinary four wheeled forklifts The drive or the power would be given to the front two wheels independent of each other and would be driven with a motor . Since the wheel would have a braking system involved in each .

\section{Left turn scenario :}

Here the wheel on the right would be given drive while the left front wheel would act as a pivot point. If in case some slip occurs in the according to floor conditions then the brake could be applied on the left wheel as the brakes of the two front wheel are independent.

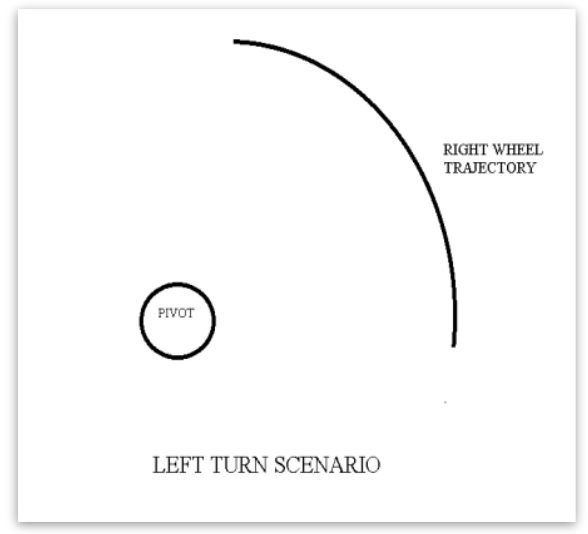

\section{FIGURE 29: LEFT TURN SCENARIO}

\section{$>\quad$ Right turn scenario :}

Now the right wheel would act as a pivot point and and the power would be provided to the left front wheel and in slip conditions the right wheel could be stopped .

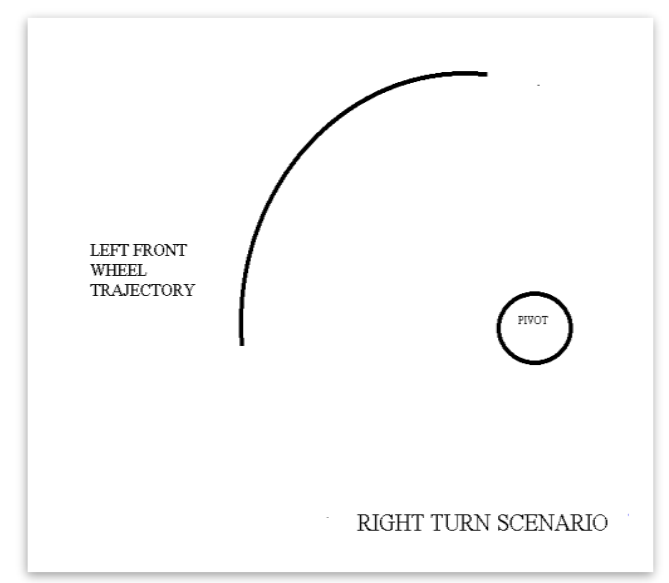

FIGURE 30 : RIGHT TURN SCENARIO

\section{On place turn scenario :}

These is the innovation added to our project it would require the minimum space to turn as both the front wheel would be rotating in opposite directions and the time also required to perform the operation would be minimum . 


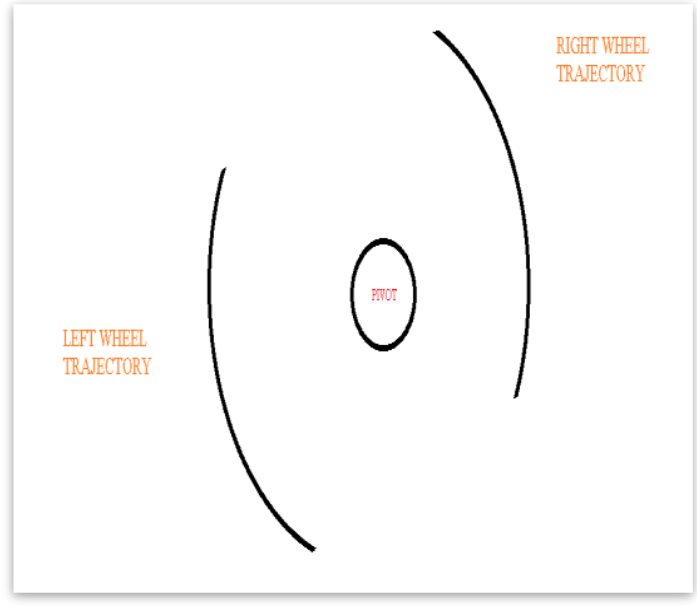

FIGURE 31 : ON PLACE TURN SCENARIO

CHAPTER 5 : IMPLEMENTATION PLAN

\section{A) COST ESTIMATION :}

\begin{tabular}{|l|l|l|}
\hline $\begin{array}{l}\text { SR } \\
\text { NO. }\end{array}$ & COMPONENTS & $\begin{array}{l}\text { ESTIMATED COST } \\
\text { (RUPEES) }\end{array}$ \\
\hline 1 & FORK & 5000 \\
\hline 2 & BRAKE ASSEMBLY & 500 \\
\hline 3 & MOTOR & 6000 \\
\hline 4 & SHAFT & 200 \\
\hline 5 & CHAIN DRIVE & 1000 \\
\hline 6 & SQUARE TUBE & 500 \\
\hline 7 & GUIDE & 1000 \\
\hline 8 & BASE PLATE & 500 \\
\hline 9 & ACTUATOR & 200 \\
\hline 10 & SWITCHES & 200 \\
\hline 11 & WARNING SYSTEMS & 100 \\
\hline 12 & BATTERY SYSTEM & 5000 \\
\hline 13 & MISCELLANEOUS & 2000 \\
\hline
\end{tabular}

\section{B) PIE CHART :}

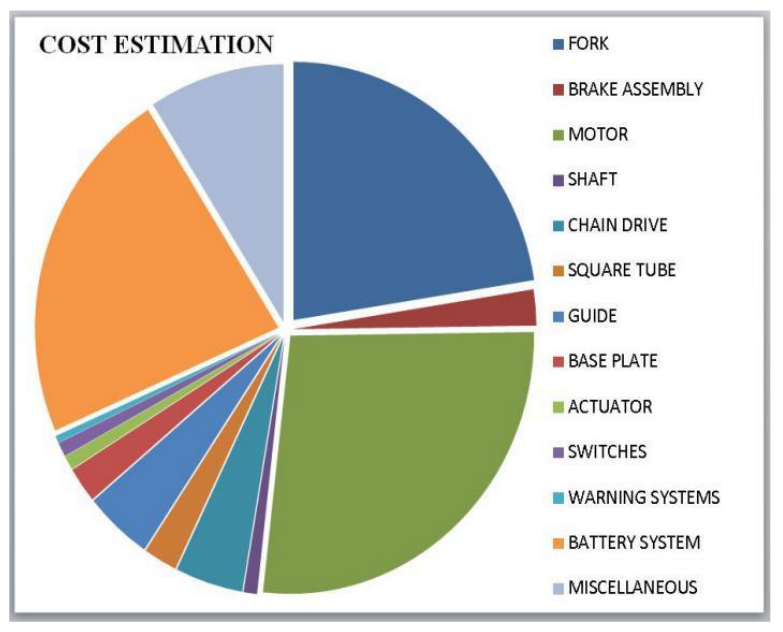

FIGURE 32 : PIE CHART

\section{CHAPTER 6 : ADVANTAGES AND DISADVANTAGES}

\section{ADVANTAGES :}

- $\quad$ Longer life

- Minimum noise level

- $\quad$ Suitable for indoor use

- Eco friendly operation

- It can be also used in hazardous areas

- Huge advantage is that it does not have fossil fuel cost

- The electric forklift has zero emissions and hence safe and healthy. It can also be called GREEN FORKLIFT

- Less maintenance due to minimum mechanical components used

- Small scale industries can also incorporate these forklifts

- $\quad$ Minimum turning radius

DISADVANTAGES :

- $\quad$ Amount of load is limited

- $\quad$ Less speed

- $\quad$ Trained personnel needed to control

- $\quad$ They are usable only indoor purpose 


\section{CHAPTER 7 : EXPECTED RESULTS AND MODEL}

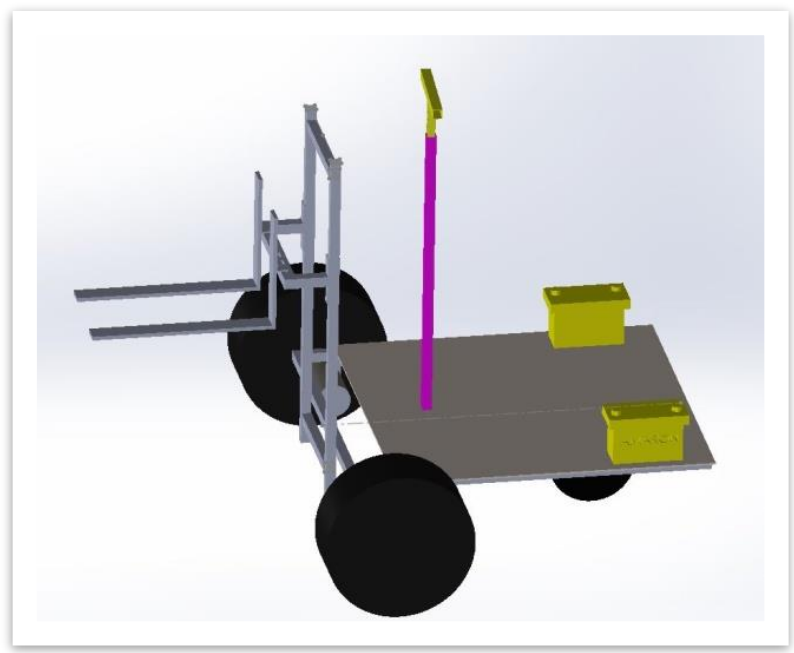

FIGURE 34 : FORKLIFT MODEL

- $\quad$ The turning radius would be minimum

- Low in cost

- $\quad$ Less hazardous to environment

- $\quad$ No fossil fuel required

- $\quad$ Eco friendly operations

- $\quad$ Can be incorporated in low scale industries

- $\quad$ Small in size compared to regular forklifts

- $\quad$ Good load carrying capacity

- $\quad$ Tough and compatible for small purpose .

\section{CONCLUSION :}

The deveploment of Mechanical forklift assures the ergonomically comfort to the operator or worker and to reduces time required for manual lifting and handling. This increases the productivity $\&$ it provide safety of operator while handling of the material.

\section{REFERENCES :}

[1] Seidl M, Dvoák Z (2011) In-house transport as a part of business logistics. J EngManagCompet 1(1/2):1-5.

[2] Masztelarz M (2010) Methods for accounting of ancillary activities' costs (Metodyrozliczaniakosztówdziałalnościpomocniczej) [IN] Gabrusewicz W. (ed.) Audyt w systemiekontroli; Conference Proceedings, KIBR, Poznan, Poland 29.11.2010 pp. 131-142 ISBN: 978-83-61287-45-2 http://www.pracownicy.ue.poznan.pl/ masztalerz/rozliczanie.produkcji.pomocniczej.pdf (in Polish) access: 5th November 2015

[3] Michałowska K (2013) Logistics costs in a company (Znaczenieisposobyrozliczaniakosztówlogistycznych);

ZeszytyNaukoweUniwersytetuSzczecińskiego $\mathrm{nr}$ 765, „Finanse, RynkiFinansowe, Ubezpieczenia^ WydawnictwoNaukoweUniwersytetuSzczecińskiego. 61(2):325334. in Polish.

[4] R S Khurmi, J.K Gupta (2005), A text book of Machine Design.

[5] S S Rattan (2009), Theory of Machines, Professor of Mechanical Engineering, National Institute of Technology, Kurukshetra.

[6] V B Bhandari (2010), Design of Machine Elements, Retired Professor and Head Department of Mechanical Engineering, Vishwakarma Institute of Technology, $\mathrm{P}$

[7] J B Gupta (2011), Basic Electrical \& Electronics Engineering.

[8] B L Thareja, A K Thareja Revised by S G Tarnekar (2005), Electrical Technology, Former Professor \& Head, Electrical Engineering Department,

[9] Visvesvaraya National Institute of Technology, Nagpur

[10] Conte M (2010) Super capacitors technical requirements for new applications. Fuel Cells 10:806-818.

[11] Hyster-Yale Materials Handling, Inc. Retrieved 15 December 2013.

[12] Brindley, James (December 2005). "The History of The Fork Lift". Warehouse \& Logistic News . Archived from the original on 200908-31.Retrieved 2008-01-25.

[13] Clark Material Handling Company. 2008. Retrieved 15 December 2013.

[14] Rudencko (hoisting equipment design) 